\title{
THE FIXATION OF ATMOSPHERIC NITROGEN BY SWEET CLOVER
}

\author{
A THESIS
}

PRESENTED TO THE FACULTY OF THE GRADUATE SCHOOL OF CORNELL UNIVERSITY FOR THE DEGREE OF DOCTOR OF PHILOSOPHY

BY

LEONARD AMBY MAYNARD 



\title{
THE FIXATION OF ATMOSPHERIC NITROGEN BY SWEET CLOVER
}

\author{
A THESIS
}

PRESENTED TO THE FACULTY OF THE GRADUATE SCHOOL OF CORNELL UNIVERSITY FOR THE DEGREE OF

\section{DOCTOR OF PHILOSOPHY}

BY

\section{LEONARD AMBY MAYNARD} Clover (Melilotus Alba Desr.) as a Green Manure under Greenhouse Conditions." 


$$
\begin{array}{r}
S 651 \\
. M 3
\end{array}
$$

Bucon. . 


\section{CONTENTS}

PAGE

Review of literature........................... 122

Sweet clover culture . . . . . . . . . . . . . . . . . . I 22

Decomposition of green manure ................. I 24

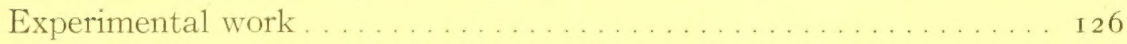

Soil used . . . . . . . . . . . . . . . . . . . . . . . . . 26

The seed ............................ I 28

The pots ............................. I30

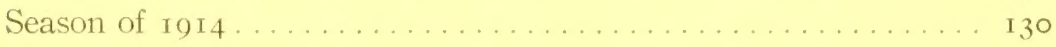

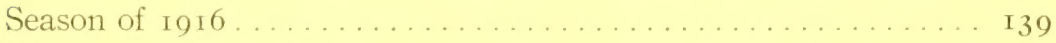

Discussion of results ..................... I 42

Production of dry matter and nitrogen ........... I 42

Percentage of fiber..................... I43

Rate of decay............................ I44

Summary ... . . . . . . . . . . . . . . . . . . . . . . . 46

Bibliography............................ 448 



\section{THE DECOMPOSITION OF SWEET CLOVER (MELILOTUS ALBA DESR.) AS A GREEN MANURE UNDER GREENHOUSE CONDITIONS ${ }^{1}$}

\section{A. MAYNARD}

The practice of green-manuring as a method of restoring and maintaining soil fertility has become more and more general as evidence regarding its value has accumulated and methods of procedure have been worked out. The choice of a green manure best suited to given conditions has been a subject of much investigation. The literature of the subject abounds with data regarding alfalfa, crimson clover, and various other plants that gather nitrogen from the air.

A plant of this type to which little attention has been given is sweet clover. This has long been regarded as a weed because of its occurrence in waste places, its general rank growth, and its ability to thrive under conditions unfavorable for the development of other plants. The fact seems to have been overlooked that these very characteristics, coupled with nitrogen-gathering power, are the features desired in a soil renovator. Recently several writers have called attention to the possibilities of sweet clover for this purpose, but experimental data are lacking. The present investigation is a study of the ability of the plant to gather nitrogen, and the rate with which this nitrogen becomes available when the plant material is incorporated with the soil.

Sweet clover obtains its name from the peculiar sweetish fragrance of its flowers, due to an ethereal oil, coumarin. The plant is known by a variety of other names, such as Melilotus, Bokhara, giant clover, and wild alfalfa. Three species are common in the United States - the white biennial (Melilotus alba Desr.), the large yellow biennial (Melilotus officinalis Lam.), and the small yellow annual (Melilotus indica A11.). This investigation concerns itself with the first species, which is commonly referred to as Bokhara, or merely as sweet clover. The name Bokhara is obtained from a district in Asiatic Russia, supposedly the original home of the plant.

Sweet clover is an erect, stemmy plant, reaching a height of from eighteen to thirty inches the first year; a single plant growing by itself will tend to branch more than do plants growing together. When young the plant resembles alfalfa, but its leaves are usually more broadly ovate and its foliage is less dense. At bloom it is easily recognized by its

\footnotetext{
1 The work described in this bulletin was done in the Department of Agricultural Chemistry, under the direction of Professor George W. Cavanaugh.
} 
perfume, a characteristic not so marked in early growth unless the plants are dried. A long taproot is early developed, which becomes fleshy toward the end of the first season due to the large quantity of reserve material stored in it. During the second season the plant makes a growth of from five to twelve feet in height. In the middle of the summer white flowers, borne on long, slender racemes, are produced. Death occurs when the seed has matured.

In common with other legumes sweet clover possesses the power, thru the agency of proper bacteria, of storing up atmospheric nitrogen thru the nodules on its roots, thus enriching the soil in which it is grown.

\section{REVIEW OF LITERATURE}

A survey of the literature of the subject shows that very little definite experimental work has been undertaken regarding sweet clover. Such work as has been done has been limited, for the most part, to the study of the plant as a forage crop and as a honey plant. Data are lacking regarding its value as a green manure. Recently several authors have pointed out its utility as a farm crop, but their writings are based on general observations rather than on experimental results.

SWEET CLOVER CULTURE

An excellent discussion of sweet clover is given by Westgate and Vinall (I9I2).2 This publication contains a survey of the distribution of the crop thruout the United States, together with some data regarding yields and the purposes for which the crop is used. Methods of cultivation are discussed, as well as the value of the plant for hay, for pasture, or for soil improvement. The authors state that sweet clover possesses a wider adaptability to soil types and climate than any of the true clovers and probably than alfalfa. Attention is called to the fact that the plant thrives in the most humid as well as the semi-arid sections of the country, and produces a satisfactory growth on both the acid soils of the East and the alkali soils of the West. It is stated further that a good stand is obtained on soils too low in humus for the favorable growth of most other legumes. Failures in obtaining a good stand are considered to be due largely to faulty culture methods and to poor germination of the seed. The authors conclude that sweet clover, properly handled, is a valuable addition to the farm crops of many sections.

Another comprehensive study of sweet clover is contained in a bulletin by Lloyd (I912). A survey of the distribution of the crop in Ohio is given, together with notes from twenty-nine foreign countries and thirty-

2Dates in parenthesis refer to bibliography, page 148. 
four of the American experiment stations. The habits, soil adaptations, and agricultural value of the plant are discussed. It is concluded that the plant is peculiarly suited to adverse conditions, that it will thrive where other legumes will not, and that as a green manure it adds more humus-forming material to the soil than do any of the other nitrogengathering plants. Lloyd states further that the best growth is secured in soils rich in lime, and that inoculation with the appropriate bacteria may be necessary.

Investigations to test the manurial value of sweet clover have been limited to a study of its effect on a succeeding crop. Orth (1892) conducted an experiment to note its effect as a green manure on succeeding crops of oats and potatoes. In May sweet clover was sown in rye, and in the summer of the following year the crop was plowed under. The yield of potatoes was doubled in comparison with that of check plats which received no green manure. Better yields were secured where sweet clover was turned under than on similar plats which received eight tons of stable manure instead of green manure. The yield of oats, grain and straw, was increased by 60 per cent and 90 per cent, respectively. Greenmanuring with sweet clover also increased the growth of maize.

Westgate and Vinall (I912:30) describe an experiment conducted in Alabama showing the effect of sweet clover on a succeeding corn crop. On poor, run-down soil, 6672 pounds of sweet clover hay per acre were produced the first year and 7048 pounds the second year. The stubble was then plowed under and the field was planted to corn, 22.7 bushels per acre being produced as compared with 16.2 bushels where sweet clover had not been sown.

Hopkins (I910:219-220) mentions some Illinois investigations with sweet clover regarding yield and nitrogen content at the end of the second season's growth. Figures are given for roots and tops separately, showing 86 per cent of the total nitrogen to be present in the latter. It is concluded from the results obtained that sweet clover gives great promise as a green-manure crop.

The bibliographical evidence indicates that sweet clover thrives under a great variety of soil and climatic conditions, and that it is peculiarly adapted to adverse situations. Data regarding yield and nitrogen content show that the plant compares favorably with the other legumes in its ability to fix nitrogen. Further, surveys indicate that good stands have been obtained where other legumes have failed. In view of all this evidence in favor of sweet clover, it is pertinent to ask why the crop has been so little utilized in general farm practice. One reason is that the plant has long been regarded as a pest, difficult to eradicate. This view has now been dispelled, as a perusal of either Lloyd's or Westgate 
and Vinall's bulletin will show. A more valid objection to sweet clover has been the difficulty experienced in obtaining a satisfactory stand, especially the first season. This has been demonstrated to have been due in part to faulty methods of cultivation, for a hard, compact seedbed is required. The difficulty has probably been due in a larger degree to poor germination because of hard seed, especially when combined with lack of inoculation. Further, the fact that sweet clover is a biennial has curtailed its use. Two years has seemed too long a time to give up a field to a soil renovator, particularly as the woody nature of the plant at maturity indicates that it would decompose slowly in the soil. The lack of accurate experimental data has doubtless been another factor in limiting the use of the crop.

A survey of the factors that have limited the utilization of sweet clover in general farm practice indicates that some exact data are needed relative to the following points: the ability of the plant to thrive on a worn-out soil; methods of increasing the germinating power of the seed; the value of lime; the possibility of securing a satisfactory yield the first season; the rate of decay of the plant material when incorporated with the soil; and the proper time for turning under to combine a satisfactory yield with rapid decay. It was with the object of throwing some light on these questions that the present investigation was undertaken.

\section{DECOMPOSITION OF GREEN MANURE}

No record has been found of any study of the rate of decay of sweet clover as a green manure. The value of green manures has been more frequently studied from the standpoint of their effect on succeeding crops than by measurements of their rate of decay. This is natural, inasmuch as the decomposition of organic matter is a complex process of many stages and no really satisfactory methods have been devised for measuring it. Decay of organic matter is caused by microorganisms, as first pointed out by Wollny (1884), and this fact has been utilized in the methods devised for studying the process.

Wollny (i 886) measured the carbon dioxide evolved during decay. This method leaves open the question as to the form into which the nitrogen of the organic matter is converted. Inasmuch as plants take up this element principally as nitrate, it is desirable to know to what extent nitrification is going on, or at least to know that conditions are favorable for this process. It is obvious that conditions which favor initial decomposition and those favorable to nitrate formation are not identical. Pagnoul (1895) has shown that under certain conditions ammonium salts may form in abundance while nitrification proper is 
retarded. It is also known that carbon dioxide may be used by microorganisms as a source of carbon, under which conditions its evolution would not be a proper measure of the rate of decay. Hutchinson and Milligan (IOI+) improved Irollny's method by supplementing the carbon dioxide measurements with nitrate determinations.

In consideration of the fact that the decay of organic matter is a bacteriological process, the prolulem of its measurement has been attacked from that standpoint. This moxte of at tack was first sugrested by Remy: The underlying principle of the method is the determination of the kind, and the intensity of the functions, of the bacteria concerned. This is accomplished by inoculating nutrient solutions with portions of the soil in question and determining the metabolic products after a given period of incubation. Many recent investigators have modified the original method. Altho the Remy scheme and its modifications have been the most widely adopted of the methods devised for studying the decay of organic matter, the procedure contains many weaknesses, as pointed out by Allen and Bonazzi (igrs).

The stage of decay which gives the most information as to the availability of a green manure is nitrate formation, since it is as nitrate that nitrogen is taken up by the plant. If nitrification has occurred, it is evident that other processes have preceded it, to furnish forms of nitrogen capable of being nitrified. The accumulation of nitrates in soils under a sreen-manure treatment has been user as a measure of the availability of the material turned under.

Inasmuch as the measurement of nitrates formed was the method finally adopted in the present investigation, it seems desirable to cite instances when this procedure has heen followed and comsiderations that have led to its adoption. Early investigators believed that the presence of organic matter retards nitrification. If this were so, the measurement of nitrate accumulation would be a poor method of studying the decomposition of a green manure. Recent work, however, seems to have disproved the earlier views. An account of the experimental work on this subject is given by Hill (I9I5), who made a thoro study of various green manures on several types of soils under greenhouse conditions. He found that organic matter, as bluegrass, clover, and alfalfa, passed over into nitrates. The addition of the green manures increased the rate of nitrate formation. Brown and Allison (I9r6) have shown that the application of the common humus-forming materials in maximum amounts for farm conditions increases ammonification and nitrification to a considerable extent. Wright ( 19 r5), working with vetch and rye, found that plowing under green manures resulted in rapid decay accompanied by vigorous nitrification. The work of Hutchinson and Milligan 
(igr4) has been referred to. These investigators studied the rate of decay of sann hemp, using the accumulation of nitrates as the measure. The plants were turned under at different stages of growth. The percentage of nitrification was found to decrease markedly with age.

The work of the last-named investigators, together with that of Hill, shows the application of the study of nitrate formation to the problem of the rate of decay of a green manure. The method is open to several objections, but so are the other methods derised. The process of nitrate formation is very sensitive to soil and atmospheric conditions, but this objection to the method is less serious in pot experiments in the greenhouse, where conditions can be carefully controlled and no nitrates are lost by leaching.

In the present investigation the crude-fiber content of sweet clover was considered. It is believed that the amount of carbohydrate material present has a bearing on the rate of decay. Hill (1915) found that pure cellulose and paper retarded nitrification. Paterson and Scott (Igra) found that starch and sugar retarded nitrification. Hutchinson and Milligan (I9If) state that the rate of decay of plant material depends on the percentage of vascular ring and lignified parts. Brown and Allison (I9I6) found that straw did not increase nitrification as much as did green manures; however, they found no relation between the nitrogen-carbon ratio and nitrification. Wright (I0) I5) found that plowing under materials such as old hay, leaves, and strawy manure, and even green manure which had become dry, reduced the quantity of available nitrogen in the soil. It appears that crops at later stages of growth decay less rapidly, not only because they contain more fiber but also because they contain less water.

\section{EXPERIMENTAL, WORK}

The experimental work described in this paper extended over two seasons. In roit a general study was made of crop yield and rate of decay at different stages of growth and under different conditions as regards liming. In Igr6 a further study was made of the period of growth which seemed most desirable on the basis of the results obtained the previous season.

\section{SOIL USED}

The soil used in the experiments was classified by the United States Bureau of Soils as Tolusia silt loam. The Volusia series occupy an estimated area of abrut 10,000,000 acres in the United States, principally in New York, Ohio, Indiana, and Pennsylvania. These soils occur in New York State to the extent of over 20 per cent of the total area, comprising about 35 per cent of the tillable land. Rerarding the general 
character of the Volusia soils, Carr (1000) I 1) states: "In recent years extreme difficulty has been experienced in seeding clover, amounting in many cases to complete failure. Corn seldom gives any yield of mature grain; wheat yields have become so low that attempts to grow this crop have been abandoned. . . . In the region occupied by the silt loam many farm homes are abandoned." Carr concludes that this unproductivity is due to poor physical condition, lack of organic matter, and general unfavorable conditions for the development of bacteria. Hence this type of soil, because of its general distribution and run-down character, is an excellent one on which to try the restorative powers of sweet clover.

The soil was obtained from the farm of Mrs. Ellen Crutts, at Varna, New York, and cance from a ficld that hiul recently receised no application of manure or commercial fertilizer. The soil contained approximately 35 per cent of pebbles too large to pass a half-inch mesh. A sample was analyzed according to the methexls describer by the Lnited States Bureau of Chemistry." The nineral constit uents were determined in the solution obtained on strong acid digestion. Phosphorus was weighed as magnesium pyrophosphate, and calcium as the oxide. Potassium was determined by the Lindo-Gladding method. The loss on ignition over a Bunsen was considered volatile matter. As a measure of the organic matter present, the oryanic carbun was detcrmined by combustion with chromic acid, using the mudification described by Cameron and Breazeale (I904). The inorganic carbon was first determined and deducted from the total obtained on combustion. A determination of humus was also made according to the procelure describerl hy the United States Bureau of Chemistry. I)ry ammonium carlonate was added to the ammoniacal solution to flocculate the clay particles before filtering. Nitrogen was obtained by the Cumning methexl, modified to include the nitrogen of nitrates, using copper wire as a catalytic agent. The nitrates were determined on a dry sample by the phenol-disulfonic-acid method. Comparisons were made in the colorimeter designed by Schreiner. The results obtained on analysis of the soil used in the first year's work were as follows. the percentages being based on the moisture-free fine soil :

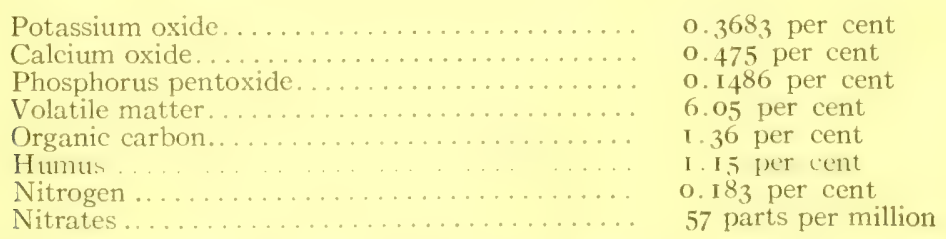

3 Official and provisional methods of analysis, Association of Official Agricultural Chemists. Bulletin 107. U. S. Bureau of Chemistry. 1908. 
In addition to the determinations listed above, the lime requirement was obtained by the Veitch method. One gram of moisture-free fine soil was satisfied by 0.00103 gram of calcium oxide, corresponding to a requirement of about 3600 pounds per acre-foot.

The soil used in the second year's work was obtained from the same place as that on which the above analyses were made. It was examined for nitrogen, nitrates, and lime requirement, with the following results:

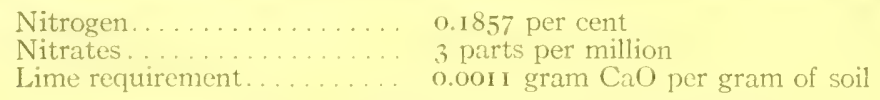

The determination for nitrates was made on the moist soil as placed in the pots, and the result ohtained was firured th the mosisture-free basis.

The results of the chemical analysis show the soil to be deficient in calcium oxide, and there is a lack of organic matter indicated by the determinations for organic carbon and humus. The figure for volatile matter is included merely for comparison with the two determinations mentioned above, as a means of showing that the loss on ignition is no measure of the organic matter present in a soil of this type. The soil is acid according to the Veitch method. The soil as analyzed contained considerable organic material still retaining a definite cell structure. This fact explains why the figure obtained for percentage of organic carbon is higher than that for humus, and, when considered with the result obtained for lime requirement, indicates that conditions were unfavorable for decomposition to proceed. Thus, not only is the soil deficient in organic matter and nitrogen, but conditions are such that the conversion of potential into actual plant food must be occurring at a very slow rate.

A striking difference in the two samples of soil is noted as regards nitrates. Tho both samples were taken at about the same time of year, the second season was a much later one. The spring months were characterized by cold, wet weather, a condition inhibiting the formation of nitrates. The crop grown on the soil the year previous to that in which the first sample was taken was potatoes; the field was in grass when the second sample was obtained. The inhibiting effect of mixed grasses on the formation of nitrates has been shown by Lyon and Bizzell (1913).

THE SEED

The seed used in the experiment was furnished by the Bokhara Seed Company, of Falmouth, Kentucky, and was obtained from a crop grown the previous year in Pendleton County, Kentucky. Inasmuch as one of the causes of failure in obtaining a satisfactory stand of sweet clover 
had been found to be due to poor sermination, it secned desirable to run germination tests on the seed used, and also to try the sulfuric-acid treatment. This methor of treating seed to increase the presentage of germination is described by Love and Leighty (I9I2). It consists essentially in allowing the seed to stand in contact with concentrated sulfuric acid until the hard seed coat is softened or removed. In these experiments sufficient acid was added to make sure that all seed was coated with it, and the mixture was allowed to stand for twenty minutes. It was then dumped into a large volume of water in order to prevent the heat of dilution from injuring the seed. Washing by decantation caused the removal of most of the loosened hulls. Finally the seed was washed on a cheesectoth filter unt il it was free from acid, and allowed to dry: The treated and the untreated seeds were then tested by germinating between filter paper. One hundred seeds were used for each trial. The results were as follows:

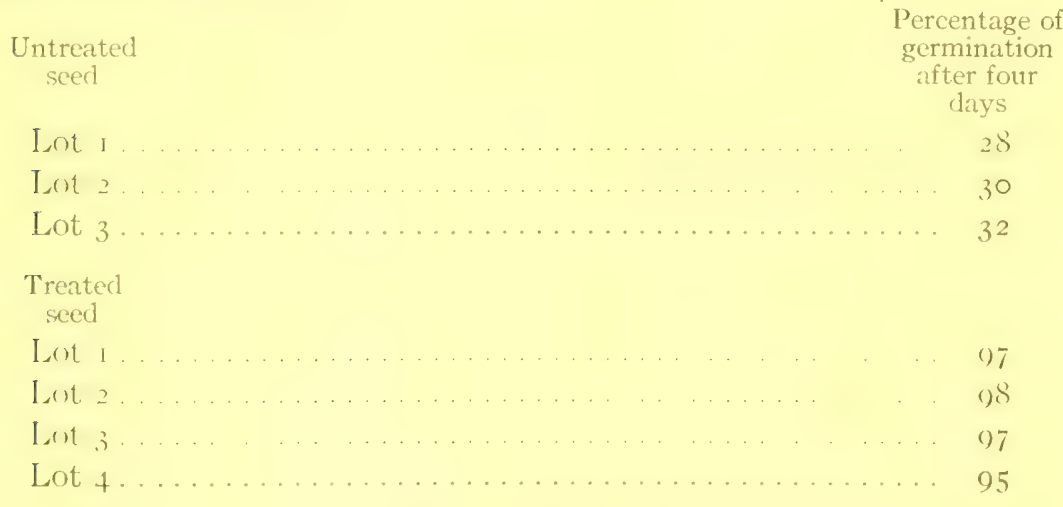

It is seen that the percentage of germination was more than trebled by the acid treatment, and that practically complete germination was obtained. Thirty per cent is probably a fair average of the results obtained by other investigators in germination tests on untreated seed. A treatment by which the quantity of seed required may be reduced by from one-half to two-thirds, should be worth while. The procedure requires little time, and the method is inexpensive since commercial acid may be used.

There may be some question whether the average farmer would be successful in treating seed by this method. In this connection it seemed desirable to investigate the effect of age on seed given the acid treatment. The following results were oftained ten months after the treatment was used: 


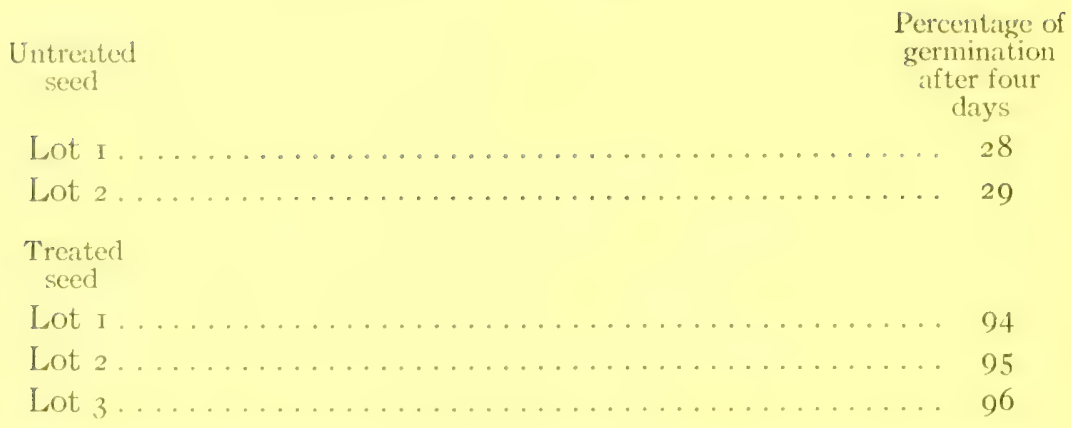

These results are important in showing that it is not necessary to reserve the acid treatment until just before the lot of seed is to be used, but that seed so treated may be kept for months with no appreciable decrease in the percentage of germination. Thus the process need not be left to the farmer, in whose hands it might not be a success, but may be carried out at the seed farm or by the dealer. ${ }^{4}$

\section{THE POTS}

The pots in which the experiments were conducted were 0.5 inches in diameter and 10 inches deep. The soil was sifted to remove the larger pebbles, and a prortion e(puivalent to about 25 pounds of moisture-free fine soil was put into each pot. The soil was inoculated with the sweetclover organism by the pure-culture method. The cultures were obtained from the Laboratory of Plant Physiolory of the New York State College of Agriculture. The pots were kept in the sreenhouse and maintained at a moisture content of 30 per cent. Quartz sand was spread over the surface of the soil to lessen evaporation.

\section{SEASON OF IOI 4}

In accordance with the procedure just described, 36 pots were set up in IoIt. In order to test the effect of lime on the growth of sweet clover, the pots were livided into three series. In one series sufficient slaked lime was arderl $t 0$ satisfy the lime requirement. while in another an equivalent quantity of finely pulverized ground limestone was used. In order to accurately meet the requirement the lime used was analyzed. The third series received no lime. The seed was placed in the pots on May 20. In sowing, the seedbed was rendered compact and the seed

\footnotetext{
${ }^{4}$ Since this work was done, Professor Hughes, of the Iowa Agricultural Experiment Station, has devised the Ames hulling and scarifying machine for the treatment of hard seed. This machine is described in Farm and Fireside, June 19, IOI5. By treatment. with it, germination is increased from 50 to 90 per cent. Many seed firms have installed the machine and have found it practical in every respect.
} 
was covered with only a thin layer of soil. At the end of ten days the plants were thinned, leaving twelve in each pot.

The pots were dirided into three groups as regarded time of harvest. At each period, four of the pots limed with hydrate, four of those limed with carbonate, and four of the check pots, were harrested. From six of these pots the roots and the tops were removed and a sample of the soil was taken. The plants from the remaining six pots were chopped up) and incorporated with the soil, pending later examination for rate of decay. Before the plant material was added a sample of the soil was taken. The pots in which the plants were turned under were kept at a moisture content of 30 per cent, in order that conditions might be favorable for decomposition. The pots from which the plants were removed were kept under similar conditions, so that they might serve as checks on any measurements made later regarding the rate of decay of the material turned under.

According to the above procedure, the thirty-six pots were harvested, in groups of twelve, on July 21, August I7, and September I 5. These dates represented periods of growth of sixty-two, eighty-nine, and one hundred and eighteen days, or approximately two, three, and four months, respectively. At each time of harvest a photograph was taken of representative pots in order to give an idea of the amount of growth and the differences noticeable according to the different treatments of the soil. These photographs are shown in figures 9, Io, and II. A foot rule is shown in each pot.

It is seen that at the end of the first period the plants had reached a height of from eight to twelve inches. Differences due to lime are not noticeable. At the end of three months a height of from fifteen to twenty inches had been attained and many lateral branches had been sent out. During the final period the height increased from five to eight inches more. This period was especially characterized, as the figure indicates, by a development of dense foliage. In both the second and the third period the effect of lime is evident.

In taking up the plants at the different periods, some observations were made regarding root development and nodule formation. During the first two periods slender taproots were developed, many attaining a length of four or five feet. During the final period the roots grew somewhat in length, but the most noticeable development was a thickening and branching a few inches below the root crown. At the first harvest it was noticed that practically all the roots bore nodules, the roots in the limed pots being more plentifully supplied. This is in accordance with what has previously been observed regarding the influence of lime on nodule formation. In no case, even at the end of the final period, 


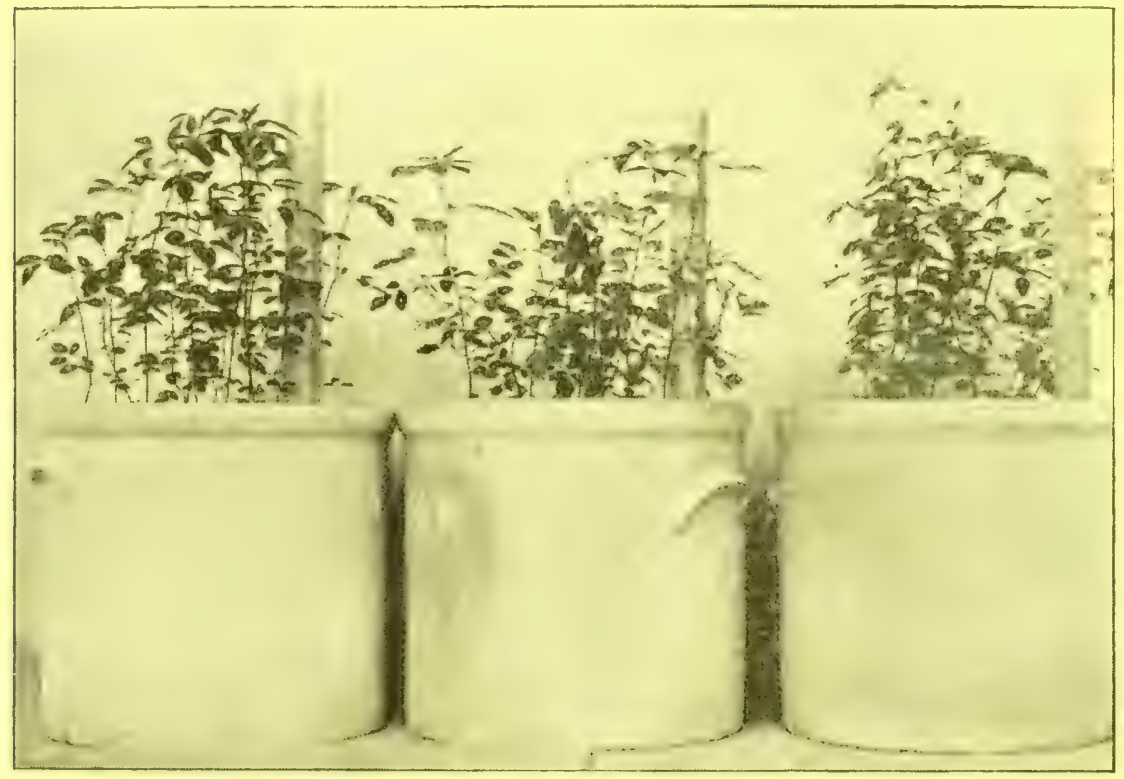

Unlimed

Slaked lime

Ciroutind limestone

FIG. 9. RESULTS FROM DIFFERENT SOIL TREATMENTS, ON PLANTS GROWN FOR 62 DAYS

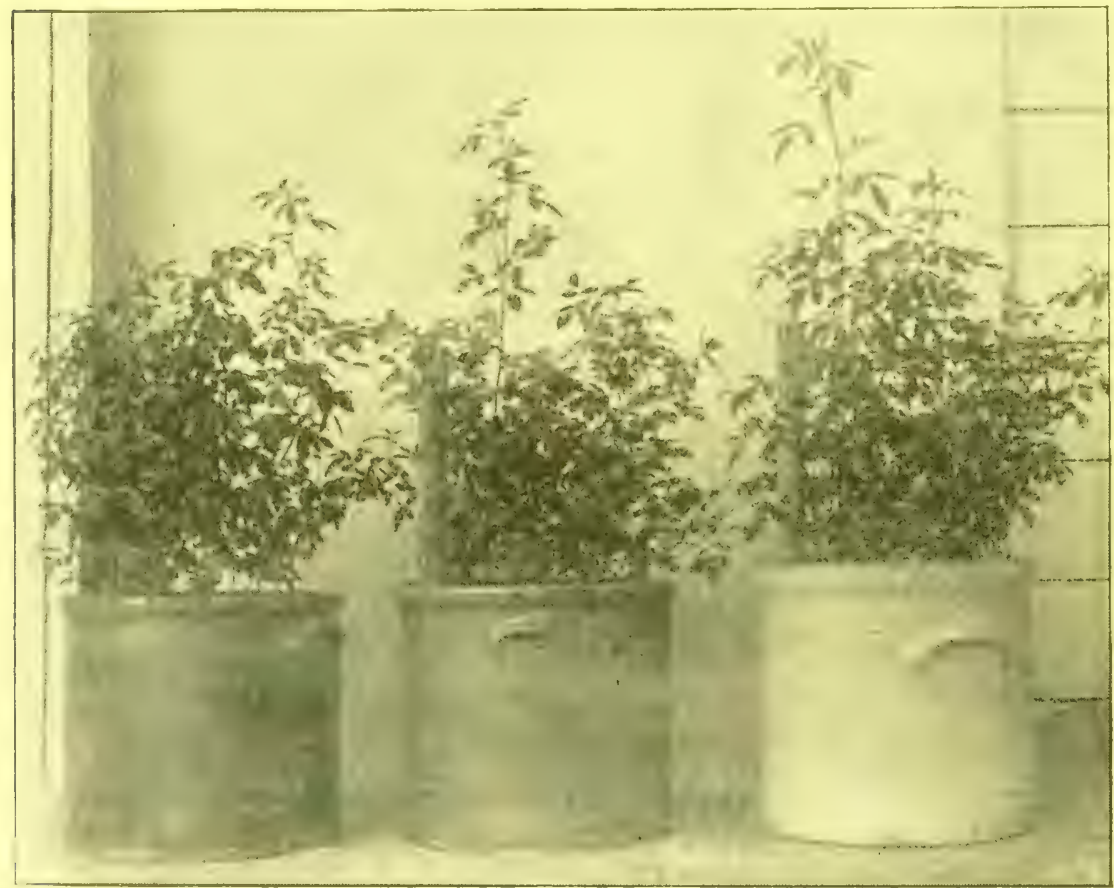




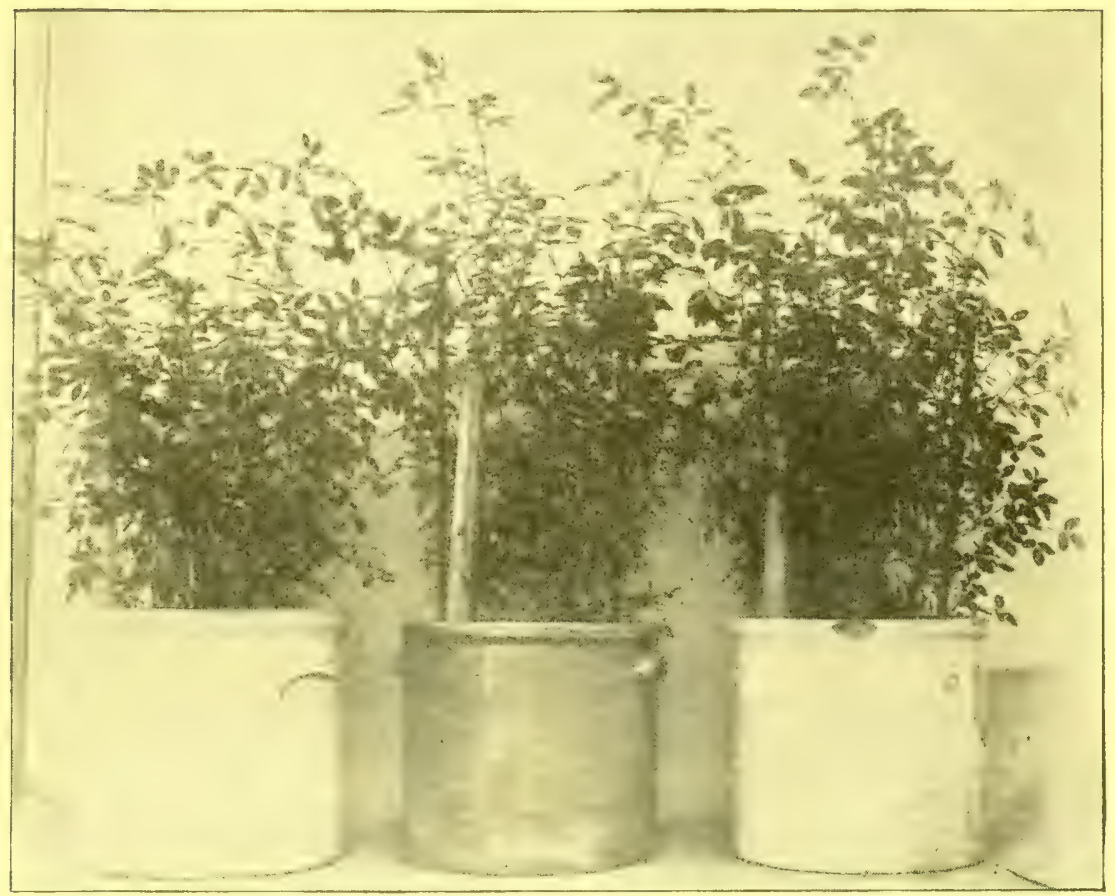

Linlined

Slaked line

Grotund limestone

FIG. II, RESULTS FROM DIFFERENT SOIL TREATMENTS, ON PLANTS GROWN FOR IIS DAYS

were large nodules formed. However, nodules were present in abundance, as is shown by the fact that as many as sixty were counted on a single root system.

The plants removed from the various pots were allowed to dry in the air and were weighed. They were then pulverized and bottled for later analysis. Similarly the sril samples were sieved and bottled after drying. These samples were analyzed for nitrates according to the methods previously described. The crops harvested were examined for nitrogen and crude fiber. The nitrogen was determined by the Gunning method, with the addition of copper wire as a catalyst. The crude fiber was determined according to the procedure outlined by the United States Bureau of Chemistry. ${ }^{5}$ This determination was deemed important because the rate of decay of any plant material must be larsely goremed by the amount of woody tissue present. Thus it is desirable to know the percentage of crude fiber present at those stages when the plant might be used as a green manure.

5 Official and provisional methods of analysis, Association of Otficial Agricultural Chemists. Bulletin 107. U. S. Bureatu of Chemistry. Ipos. 
The results of the examination of the plant material are given in tables 1,2 , and 3 :

TABLE I. Yield ANd Composition of Crops

(Duration of growth, 62 days)

\begin{tabular}{|c|c|c|c|c|c|}
\hline \multirow[b]{2}{*}{ Pot } & \multirow[b]{2}{*}{ Treatment } & \multicolumn{2}{|c|}{ Dry matter produced } & \multirow{2}{*}{$\begin{array}{l}\text { Nitrogen } \\
\text { produced } \\
\text { (grams) }\end{array}$} & \multirow{2}{*}{$\begin{array}{l}\text { Crude } \\
\text { fiber } \\
\text { (per cent) }\end{array}$} \\
\hline & & Grams & $\begin{array}{c}\text { Percentage } \\
\text { of } \\
\text { nitrogen }\end{array}$ & & \\
\hline I & Unlimed. & 2.39 & $3 \cdot+1$ & 0.08150 & 20.50 \\
\hline 2 & Unlimed. & 2.62 & 3.29 & 0.08620 & 20.01 \\
\hline 5 & Slaked lime. & 2.25 & $3 \cdot 52$ & 0.07920 & 21.04 \\
\hline 6 & Slaked ime. & 2.55 & 3.40 & 0.08670 & 23.19 \\
\hline 9 & Ground limestone... & 2.82 & $3 \cdot 43$ & 0.09673 & $21 \cdot 13$ \\
\hline 10 & Ground limestone... & $2.5 \mathrm{I}$ & 3.53 & 0.08860 & $21 \cdot 78$ \\
\hline
\end{tabular}

TABle 2. Yield and Composition of Crops

(Duration of growth, 89 days)

\begin{tabular}{|c|c|c|c|c|c|}
\hline \multirow[b]{2}{*}{ Pot } & \multirow[b]{2}{*}{ Treatment } & \multicolumn{2}{|c|}{ Dry matter produced } & \multirow{2}{*}{$\begin{array}{l}\text { Nitrogen } \\
\text { produced } \\
\text { (grams) }\end{array}$} & \multirow{2}{*}{$\begin{array}{l}\text { Crude } \\
\text { fiber } \\
\text { (per cent) }\end{array}$} \\
\hline & & Grams & $\begin{array}{c}\text { Percentage } \\
\text { of } \\
\text { nitrogen }\end{array}$ & & \\
\hline 13 & Unlimed. & $9.6 \mathrm{I}$ & $3 \cdot 42$ & 0.3287 & 25.33 \\
\hline 14 & Unlimed. & 8.81 & 3.57 & 0.3145 & 23.63 \\
\hline 17 & Slaked lime. & 12. 10 & 3.59 & $0.434+$ & 25.82 \\
\hline I 8 & Slaked lime. & 10.50 & 3.72 & 0.3906 & 25.63 \\
\hline 21 & Ground limestone... & I I. 45 & 3.79 & 0.4340 & 23.84 \\
\hline 22 & Ground limestone... & HI. IO & 3.86 & 0.4285 & $2+.51$ \\
\hline
\end{tabular}

TABLE 3. Yield AND COMPOSITION OF CROPS

(Duration of growth, i 8 days)

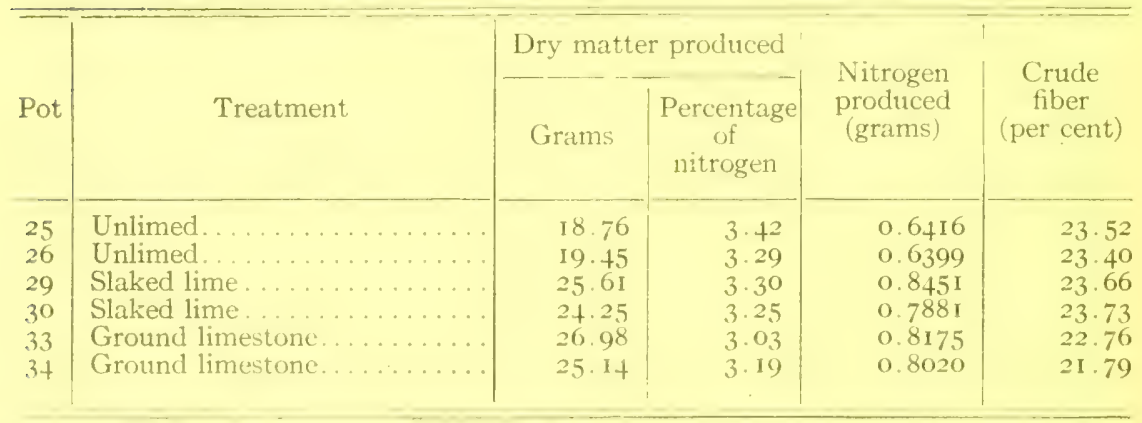


It is seen in table I that little dry matter was produced in the first two months of growt hand that no differences due to liming are discernible During the third month the growth increased fourfold on the unlimed pots and an even greater growth resulted in the soil to which lime had been added. The dry matter produced during the first three months was doubled during the fourth, and here again the effect of lime was manifest. The results indicate that in order to obtain the largest yield the lime requirement of the soil should be satisfied; the yields for the two kinds of lime do not differ sufficiently, however, to permit any suggestion as to which is the better form to apply.

The results for nitrogen content show that sweet clover compares favorably in this respect with other legumes. The percentages do not vary widely, but the figures indicate that the nitrogen content per gram of dry weight reaches a maximum before the end of the four-months growth. The figures showing the amount of nitrogen produced follow those for dry matter rather closely.

The percentage of fiber appears to be somewhat greater at the end of the second period of growth than at either of the other times of examination. This sems rather surprising, but probably may be explained on the basis of the cultural observations made. It was observed that during the second period the greatest increase in height and thickness of stems occurred, while the final period was characterized by a development of foliage. Thus in the last period a proportionally smaller amount of woody tissue was formed and the percentage of crude fiber dropped. A comparison of reported analyses of sweet clover for fiber shows a wide variation in the results obtained, depending on the locality, the time of cutting, and other factors. In general, analyses show a crude fiber content of from 30 to 35 per cent at blooming time the second season. From the standpoint of rate of decay, the crop should be of much more value at the end of the first season, when the fiber content is from ro to I 5 per cent less.

Figuring the results obtained in the pot experiments to the acre basis, it is found that at the end of the four-months growth the yield from the pots limed with ground limestone corresponds to about two tons per acre. The nitrogen produced corresponds to II 5 pounds per acre, an amount to supply which would require ten tons of stable manure. It is realized that this computation is of limited value, in that considerable error may enter into the calculation. Further, it is realized that results under field conditions might vary considerably from those obtained in pot experiments. However, the figures are useful for the interpreta tion of the results given in the tables, and they indicate what sweet clover would do in the same soil in the field under optimum conditions. 
It has already been stated that no method has been devised which will measure the rate of decay of organic matter thru all its stages, and that none of the methods in use at the present time for studying this problem are free from objections. The question aruse as to whether a more satisfactory method could be devised. In this connection it seemed possible that some modification of the alkaline permanganate method as devised by Jones (1912) might be applicable. In this method a sample containing 50 milligrams of water-insoluble organic nitrogen is washed free from soluble salts, and digester below the distillation point with a definite amount of alkaline permanganate of definite strength for thirty minutes. The temperature is then raised, and during the next sixty minutes 95 cubic centimeters of the sample is distilled over intu standard acid. The nitrogen thus obtained is designated as active water-insoluble nitrogen. It is considered to be that portion which will rapidly become available for plant use. The methoc has demonstrated its value in differentiating between high- and low-grade sources of nitrogen in commercial fertilizers. Its disadrantages are that it is empirical and may give varying results with different investigators. As regards its adaptability to the determination of the availability of soil nitrogen, it seemed possible that with a given soil and a given source of oryanic matter the rate of decay might be indicated by the increasing amounts of ammonia distilled from the permanganate solution. It seemed that if the manipulations were carried out with exactness, restilts comparable with one another might be obtained. The pussibility was considered worthy of experiment.

After a number of trials of the alkaline permanganate method, it was found to be inapplicable to the purpose desirel. I ferv of the results obtained are given, because of their bearing in explaining the failure of the method. A sample of soil containing the prescribed amount of oryanic nitrogren was treated according to the procedure outlined for a fertilizer material. Similarly, a sample of plant material was examined. Next, a composite sample of soil and plant material containing the required amount of organic nitrogen was run. The active nitrogen obtained was about 25 per cent below the theoretical amount on the basis of the materials examined separately. Using a larger amount of permanganate solution, the results were somewhat higher but still did not equal the theoretical. Samples of soil were next examined with varying amounts of the reagent. The following results were obtained:

Amount of reagent

(cubic centimeters)

roo (prescribed amount) . . . . . . . . . . .

I25 . .

I 50 .

200
Active nitrogen

(grams)

○. о1 876

0.02072

0.02310

0.02501 
Thus the amount of active nitrogen increased with the amount of the reagent. On examination it was found that the supernatant liquid in the Kjeldahl flask after digestion was colorless in each case. This showed that all the permanganate had been used up); thus it, and not the orranic matter, became the limiting factor in determining the amount of nitrogen obtained. It became evident that the reagent was reacting with other substances besides the organic matter, notably the iron of the soil. A trial on the portion of the soil remaining after ignition showed this to be true. It was thus seen that the alkaline permanganate method was not applicable to the determination of the availability of soil-organic nitrogen unless the organic matter could be seprated from the mineral part. In this connection the method of separating the organic from the mineral constituents of commercial fertilizers as devised hy Jones and Anderson (1914) suggested itself. Jones has applied this method to muck soils high in organic matter. It was not fomel to work satisfactorily for light soils, and was not applicable to the work with Volusia silt loam.

Attention was next turned to the methods previously mentioned as used in measuring rate of lecay: and, inasmuch as thesc experiments were conducted under well-defined conditions, it was decided to adopt the method of determining the nitrates formed. It was further decided to study only the pots in which the crops had been turned under at the end of the second and third periods, since the dry matter produced at the end of two months growth proved to be too little to make profitable the turning-under of a crop at this period. At harvest, the nitrates were determined in all the pots of the last two series. The pots were then kept under constant conditions for four months and the nitrates arain determined. At the beginning of the period an effort was made to have the soil at the same degree of compactness so that the oxyen supply might not vary, and a moisture content of 30 per cent was maintained thruout.

It is realized, of course, that nitrates accumulated under a green manure may not necessarily have resulted from its decomposition. It may be considered that the green manure is changed to nitrates, or it may be considered that the organic matter increases the nitrification of sources of nitrogen already present in the soil. Doubtless both these processes obtain. However, where check pots having no green manure are used, as in these experiments, the net gain in nitrates as a result of adding the green manure can be shown. The production of available nitrogen as a result of the addition of the organic matter is thus shown. and this is really the object of an experiment of this kind.

The samples taken for the nitrate determination were allowed to air-dry before the analysis was made and the results were then figured to the moisture-free basis. It is realized that in drying in air, nitrate formation is accelerated, and that as a consequence the results so obtained 
are higher than when the examination is made immediately after sampling. Circtimstances prevented the following of the latter procedure. Inasmuch as the samples taken when the crop was turned under, and after the period of four months, were handled identically, the figures for the difference in nitrate content at these periods should not be greatly affected by the increase due to drying.

The nitrates formed during four months in the pots having the plants removed or turned under after a growth of $8_{9}$ days, are shown in table 4 , and in table 5 are shown the same results for the II8-days period:

TABLE 4. Formation of Nitrates

(Crop turned under after 89 days growth)

\begin{tabular}{|c|c|c|c|c|}
\hline Pot & Treatment & $\begin{array}{c}\text { Treatment of crop } \\
\text { at harvest }\end{array}$ & $\begin{array}{l}\text { Nitrates } \\
\text { at } \\
\text { harvest } \\
\text { (parts per } \\
\text { million) }\end{array}$ & $\begin{array}{l}\text { Nitrates } \\
\text { after } \\
\text { four months } \\
\text { (parts per } \\
\text { million) }\end{array}$ \\
\hline 13 & Unlimed. & Removed. & 72 & 59 \\
\hline 14 & Unlimed & Removed. & 59 & 53 \\
\hline 15 & Unlimed. & Turned under. & 55 & 45 \\
\hline 16 & Unlimed. & Turned under. & 69 & 60 \\
\hline 17 & Slaked lime. & Removed. & 76 & 70 \\
\hline 18 & Slaked lime. & Removed. & 87 & 87 \\
\hline 19 & Slaked lime. & Turned under. & 89 & 148 \\
\hline 20 & Slaked lime. & Turned under. & 124 & $2 \mathrm{I} 2$ \\
\hline 21 & Ground limestone. & Removed. . & 149 & 209 \\
\hline 22 & Ground limestone. & Removed. & 140 & I 81 \\
\hline 23 & Ground limestone. & Turned under. & 160 & 339 \\
\hline 24 & Ground limestone. & Turned under. & 129 & 270 \\
\hline
\end{tabular}

TABLE 5. Formation OF Nitrates

(Crop turned under after $1 \mathbf{8}$ days growth)

\begin{tabular}{|c|c|c|c|c|}
\hline Pot & Treatment & $\begin{array}{c}\text { Treatment of crop } \\
\text { at harvest }\end{array}$ & $\begin{array}{l}\text { Nitrates } \\
\text { at } \\
\text { harvest } \\
\text { (parts per } \\
\text { million) }\end{array}$ & $\begin{array}{l}\text { Nitrates } \\
\text { after } \\
\text { four months } \\
\text { (parts per } \\
\text { million) }\end{array}$ \\
\hline $\begin{array}{l}25 \\
26 \\
27 \\
28 \\
29 \\
30 \\
31 \\
32 \\
33 \\
34 \\
35 \\
36\end{array}$ & 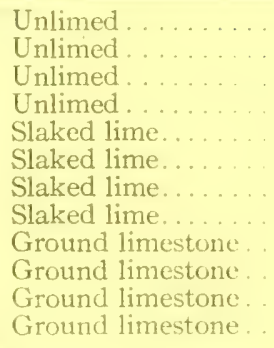 & 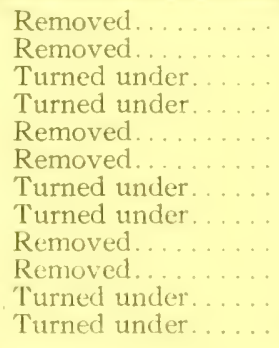 & $\begin{array}{r}54 \\
61 \\
72 \\
66 \\
99 \\
145 \\
135 \\
147 \\
70 \\
66 \\
140 \\
124\end{array}$ & $\begin{array}{r}76 \\
64 \\
185 \\
122 \\
185 \\
225 \\
319 \\
422 \\
136 \\
107 \\
444 \\
367\end{array}$ \\
\hline
\end{tabular}


It is moted that in each peried there were fond pots treated allike ats regards liming, and that at harvest the erop was remored from two of these pots and turned under in the other two. It is natural that nitrification should have occurred in all the pots, with the possible exception of the unlimed ones, due to the favorable conditions maintained.

The original soil contained 57 parts of nitrate per million on the moisture-free fine basis, or 5.3 parts per million in the dry soil as put into the pots. Thus by noting the figures for nitrates at harvest it is seen that there was an increase during the period of growing the crop, an increase more marked in the limed pots. In table 4 it is shown that in the unlimed pots the nitrates did not increase in the four months following harvest. It may be assumed that decomposition occurred to some extent, as evinced by the fact that at the end of the period the plant material, with the exception of a few roots. could not be distinguished in the soil, but that conditions were not right for complete decay. In table 5 it is seen that following harvest the nitrates increased somewhat in the unlimed pots from which the crop was removed, and that there was a decided increase in the pots in which the material was turned under. Nitrate formation was much greater in the limed than in the unlimed pots.

The examination of the original soil placed in the pots when the culture experiments were started indicated that conditions had been unfavorable for decomposition processes to go on. It may be considered that the physical conditions and the water relationships for the soil in the pots were more favorable for decay than the conditions obtaining in the field from which the soil was taken. However, a comparison of the results obtained for the limed and the unlimed pots indicates that lime was the larger factor in bettering the (onditions favoring decomposition, due to its effect in producing a more favorable medium for the activity of micro organisms.

A study of tables 4 and 5 shows that the results vary rather widely in duplicate pots, and makes evident the sensitiveness of nitrate formation to slight variations even under accurately controlled conditions. In the discussion at the end of this paper the probable errors of the results are computed, in order to show how larye rariations may be expected under the conditions of these experiments.

\section{SEASON OF IQI6}

The experimental work conducted in I9I4 was repeated in part in 19r6. The data obtained in the first season indicated that, from the standpoint of amount of available green manure produced, the fourmonths period gave the best results. Consequently, it was decided to 
grow the plants for this period in 19 ) 6 before turning under. In view of the previous season's work it seemed desirable that a repetition of the experiment should profuce results of greater value in drawing conclusions as to rate of decay. It was hoped that the variations in the results for nitrate formation might be reduced by a repetition of the work.

The soil used in the second season's work is described on page I 26. Seed was again obtained from the Bokhara Seed Company. Four pots limed with slaked lime, four limed with ground limestone, and four unlimed, were set up. The seed was sown on June 2 .

The cultural observations made were similar to those reported for I9I4. During the first six weeks differences due to lime were not noticeable. Thereafter, however, more rapid growth on the limed soil became increasingly evident. Toward the end of the growing period the plants on the unlimed soil were characterized by an unhealthy color and by the dying of the leaves.

The plants were harvested after a growth of I 6 days. The roots and the tops were removed from all the pots and a sample of the soil was taken. As in I9I4, the plants from two pots of each series as regards liming were saved for analysis. The plants from the remaining pots were incorporated with the soil. All pots were then maintained at a moisture content of 30 per cent, pending later examination for ra e of decay.

In taking up the plants it was evident that the roots did not bear as many nodules as in I0I4, but the nodules were somewhat larger. The limed plants were nore plentifully supplied and their root systems were much better developed. This was markedly shown by branching at the crown.

The plants removed were allowed to air-dry and were then analyzed, as in I9I4. The results are given in table 6 :

\section{TABLE 6. Yield and Composition of Crops}

(Duration of growth, I 16 days)

\begin{tabular}{|c|c|c|c|c|c|}
\hline \multirow{2}{*}{ Pot } & \multirow{2}{*}{ Treatment } & \multicolumn{2}{|c|}{ Dry matter produced } & \multirow{2}{*}{$\begin{array}{l}\text { Nitrogen } \\
\text { produced } \\
\text { (grams) }\end{array}$} & \multirow{2}{*}{$\begin{array}{l}\text { Crude } \\
\text { fiber } \\
\text { (per cent) }\end{array}$} \\
\hline & & Grams & $\begin{array}{c}\text { Percentage } \\
\text { of } \\
\text { nitrogen }\end{array}$ & & \\
\hline $\begin{array}{l}40 \\
4 \mathrm{I} \\
44 \\
45 \\
48 \\
49\end{array}$ & 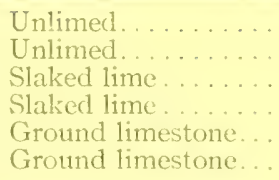 & $\begin{array}{l}18.76 \\
17.77 \\
33.65 \\
30.94 \\
29.45 \\
25.51\end{array}$ & $\begin{array}{l}2.77 \\
2.79 \\
3.22 \\
3.00 \\
2.97 \\
3.32\end{array}$ & $\begin{array}{l}0.5197 \\
0.4958 \\
\text { I. } 0835 \\
0.9282 \\
0.8747 \\
0.8469\end{array}$ & $\begin{array}{l}23.13 \\
24.24 \\
23.34 \\
22.05 \\
23.85 \\
24.85\end{array}$ \\
\hline
\end{tabular}


These results substantiate those obtainer in Iort. $\Lambda$ comparison of tables 3 and 6 shows that lime produced a somewhat greater effect in I916 than in the previous season. The figures for percentage of nitrogen are similar except as regards the unlimed pots. It was noted that the plants growing on the unlimed soil appeared less vigorous in I9 6 than in I9I4. That they were poor in color, indicating lack of nitrogen, has already been stated. The figures for fiber content agree fairly closely with those obtained the previous season.

The samples of soil taken at harvest were examined for nitrates in the moist condition. Inasmuch as the drying of a soil is known to affect its nitrate content, it was thought that this procedure might give more accurate and more uniform results than were obtained in igi4. Following harvest the pots were maintained at a moisture content of 30 per cent for four months. During this period all possible care was taken to keep conditions similar in the different pots. In sampling the soil at the end of the four-months period, no tops still showing their original form were found; however, several undecomposed root crowns were found in each of the pots in which the plants had been turned under. The samples of soil taken at this period were also examined for nitrates immediately after sampling. The results of these determinations are given in table 7 :

TABLE 7. Formation of Nitrates

(Crop turned under after 196 days growth)

\begin{tabular}{|c|c|c|c|c|}
\hline Pot & Treatment & $\begin{array}{c}\text { Treatment of crop } \\
\text { at harvest }\end{array}$ & $\begin{array}{l}\text { Nitrates } \\
\text { at } \\
\text { harvest } \\
\text { (parts per } \\
\text { million) }\end{array}$ & $\begin{array}{l}\text { Nitrates } \\
\text { after } \\
\text { four months } \\
\text { (parts per } \\
\text { million) }\end{array}$ \\
\hline $\begin{array}{l}40 \\
41 \\
42 \\
43 \\
44 \\
45 \\
46 \\
47 \\
48 \\
49 \\
50 \\
51\end{array}$ & 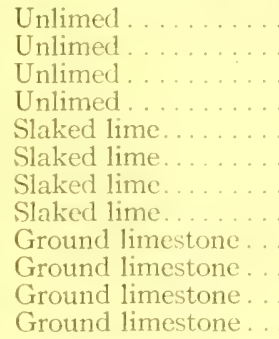 & 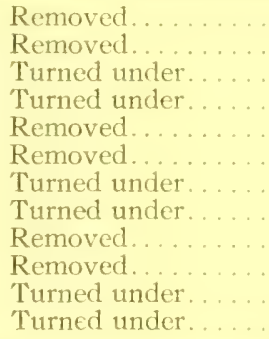 & $\begin{array}{r}5 \\
7 \\
5 \\
4 \\
17 \\
11 \\
9 \\
17 \\
8 \\
14 \\
8 \\
9\end{array}$ & $\begin{array}{r}20 \\
24 \\
47 \\
25 \\
60 \\
41 \\
283 \\
230 \\
52 \\
60 \\
240 \\
228\end{array}$ \\
\hline
\end{tabular}

The soil used in I9I6 contained 3 parts of nitrates per million. It is seen from the table that there was an increase as a result of growing the crop, and that the increase was more marked in the limed pots. The results oftatined for nitrate formation due to turning under the crop' follow, in general, those obtained in the previous season. A statistical study of this table is made in the general discussion of results. 


\section{DISCLSSION OF RESULTS}

A brief discussion of the results furnished by this investigation has been given following the tables in which the data obtained are listed. For a consideration of the results to determine what conclusions may be drawn from the experimental work, it is necessary to study the data for both seasmons as a unit, and in so far as possible to apply statistical methods in this study.

\section{Production of dry matter and nitrogen}

A glance at table I (page 134) shows that the different methods of treatment did not result in any evident differences in production for the first period of growth. A comparison of the yields listed in this table with thrse wiven in tables 2 and 3 . indicates that it is not desirable to turn under the crop at this stage of growth.

That the effect of lime is evident during the second period of growth is indicated in table 2. In order to decide how conclusive the results were, the probable errors of the means were computed according to Peter's formula, ${ }^{6}$

$$
\mathrm{E}_{\mathrm{m}}= \pm 0.8453 \frac{\left.\frac{\mathrm{v}}{\mathrm{n}}+\mathrm{d}\right)}{\mathrm{n} \sqrt{\mathrm{n}-1}} .
$$

in which $\Sigma(+d)$ denotes the sum of the deviations of every observation from the mean, their signs heing disregrarded, and $n$ represents the number of observations. In comparing two means the probable error of the wain dute to a siren treatment was computed according to the formula

$$
\text { E } \quad \sqrt{E_{1}}=+E_{2}{ }^{2} \text {, }
$$

in which $E_{1}$ is the probable error of one mean and $E_{2}$ of the other. The results of these computations are viven in table 8 , in which the different treatments are lettered $\mathrm{A}, \mathrm{B}$, and $\mathrm{C}$ :

TABle 8. Statistical. Study of Table 2

Treatment
Mean grams of dry matter
Mean grams of nitrogen
(A) Unlimed
(B) Slaked lime
(C) Ground limestone

Gain, B over A .

Gain, C over A ......
$9.2 \mathrm{I} \pm .34$

II. $30 \pm .68$

II $28 \pm$. I 4

$0.3216 \pm .0060$

$0.4125 \pm .0185$

$0.4313 \pm .0022$

$2.09 \pm .76$

$2.07 \pm .37$
$0.0909 \pm .0194$

o. $1097 \pm .0064$

B A probable error based on two determinations does not necessarily represent strictly the actual frequency diagram, and this must be borne in mind in considering many of the probable errors computed in this bulletin. A discussion of the probable error when the number of observations is small is given in an article in Biomelrika, volume 6, entitled The Probable Error of a Mean. 
Assuming that odds of 30 to I represent a chance which is practical certainty, a gain must be $3 . \mathrm{I} 2$ times its probable error to make certain its significance. On this basis it is seen that the gains calculated in table $\&$ are significant, except that for dry matter from the slaker-lime pots in comparison with the unlimed pots. Here the gain falls just below the value postulated to denote certainty. It is believed, howerer, that table 8 , taken as a whole, shows that the effect of lime was evident during the second period of growth.

In considering the results obtained for four months growth, tables 3 and 6 are available. Thus four yields for a given treatment are averaged to obtain the mean. In computing the probable errors of these means the same formulas were used as for table 8. The results are given in table 9:

TABLE 9. Statistical Study of TABles 3 ANd 6

\begin{tabular}{|c|c|c|}
\hline Treatment & $\begin{array}{l}\text { Mean grams of } \\
\text { dry matter }\end{array}$ & $\begin{array}{l}\text { Mean grams of } \\
\text { nitrogen }\end{array}$ \\
\hline $\begin{array}{l}\text { (A) Unlimed } \ldots \ldots \ldots \ldots \ldots \ldots \\
\text { (B) Slaked lime } \ldots \ldots \ldots \ldots \ldots \\
\text { (C) Ground limestone } \ldots \ldots \ldots \ldots\end{array}$ & $\begin{array}{l}18.69 \pm .22 \\
28.61 \pm 1.80 \\
26.77 \pm .71\end{array}$ & $\begin{array}{l}0.5743 \pm .0324 \\
0.9112 \pm .0462 \\
0.8353 \pm .0148\end{array}$ \\
\hline 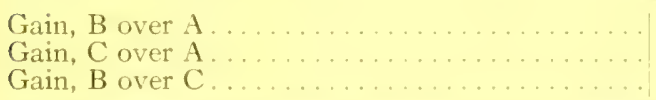 & $\begin{array}{l}9.92 \pm 1.81 \\
8.08 \pm .74 \\
1.84 \pm 1.94\end{array}$ & $\begin{array}{l}0.3369 \pm .0566 \\
0.2610 \pm .0362 \\
0.0759 \pm .0 .484\end{array}$ \\
\hline
\end{tabular}

A perusal of table 9 shows that the gains due to lime are significant but when the two kinds of lime are compared the difference is not sufficient to allow of any conclusion. The limed crop produced, roughly, 50 per cent more dry matter and nitrogen than did the unlimed.

\section{Percentage of fiber}

A study of the tables does not reveal any differences in fiber content due to different methods of treatment. It is indicated, however, that

TABle io. Statistical Study of Crude-Fiber Content

Duration of growth

(months)

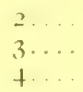

Gain, 3 months over 2 montlis.

Gain, 4 months over 2 months.

Gain, 3 months over + months.
Mean percentage

of crude fiber

$212 x+32$

$2+.79 \pm .32$

$2.3 .30 \pm 2.5$

$3.51 \pm .45$

$2.08 \pm .+1$

I $+3 \pm .+\mathrm{I}$ 
there is a difference due to time of harvest. Therefore, the averages of the results obtained for the different periods are listed, with their probable errors computed according to Peter's formula. For the fourmonths period the results of both years are included. The figures are given in table 10.

From this table it is evident that the fiber content was least at the end of the first period of growth. There was also a small decrease during the last period as compared with the second. While this may not be a general characteristic, that it did obtain under the conditions of these experiments was indicated by cultural observations as well as by analysis. It may be concluded that from the standyoint of fiber content there is no disadvantage in allowing sweet clover to grow for the four-months period before turning it under for green manure.

\section{Rate of decay}

The variations in the values tabulated as a result of the nitrate determinations make evident the necessity of computing probable errors before discussing these values. A statistical study of nitrate formation, made up from the data listed in tables,+ 5 , and 7 , is given in table $I$. For

TABLE I1. Statistical Study of Nitrate Formation

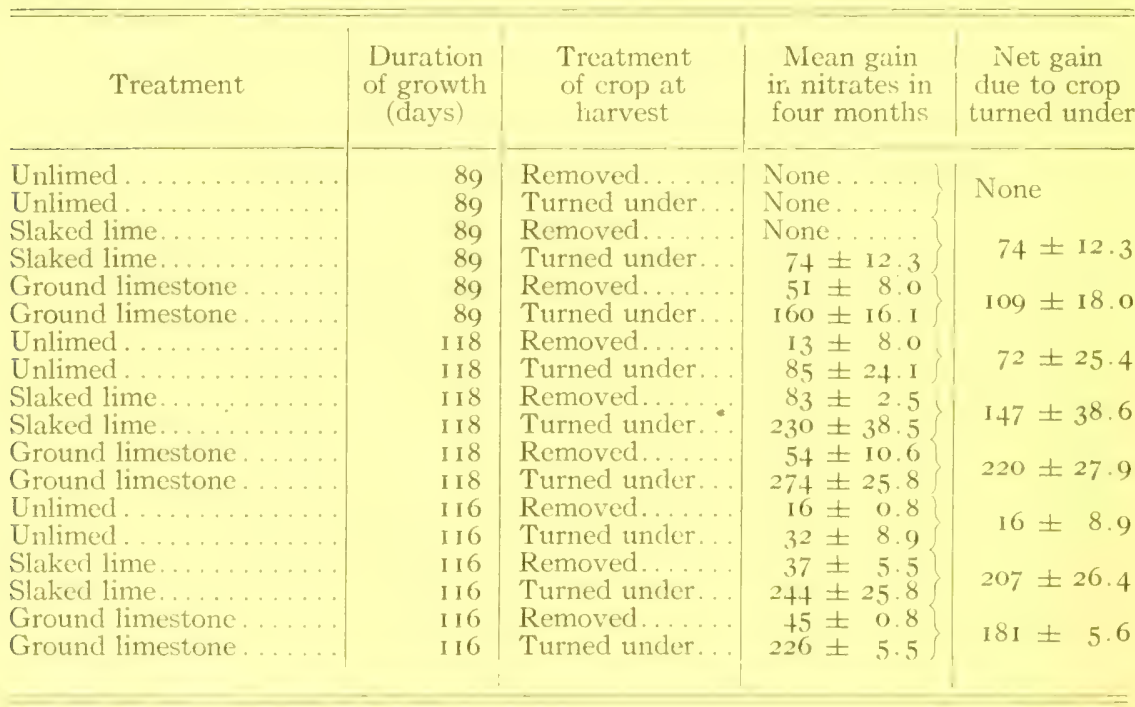

a given pot the nitrates at harvest were subtracted from those found after four months. The values obtained for each pair of pots treated alike at harvest were averaged, resulting in the column headed Mean gain in nitrates in four months. Next, for a given treatment as regards liming, 
the mean gain in nitrates for the pot from which the crop was removed was subtracted from the value for the pot in which the material was turned under. This calculation gave the net rain in nitrates due to the green manure added. These figures appear in the last column of the table. The probable errors were computed according to Peter's formula.

In the unlimed pots of the three-months period, no nitrates were formed following harrest, but on the contrary denitrification occurred. For the longer periods, nitrate formation took place to some extent in the unlimed pots both in IgI4 and in IgI6, but the probable errors attached to the values for net gain are so large as to render them of doubtful significance. The favorable effect of lime is indicated in the table, but no significant differences appear for the two kinds. The figures indicate also that a larger net gain in nitrates is obtained by growing the crop for the longer period.

The percentage of the nitrogen in the plant material added, which was changed to nitrates during the four-months periof following harvest. is shown in table I2. The figures for grams of nitrogen added are taken

TABle 12. Percentage of Nitrogen Added in Crop, Changed to Nitrate in FOUR MONTHS

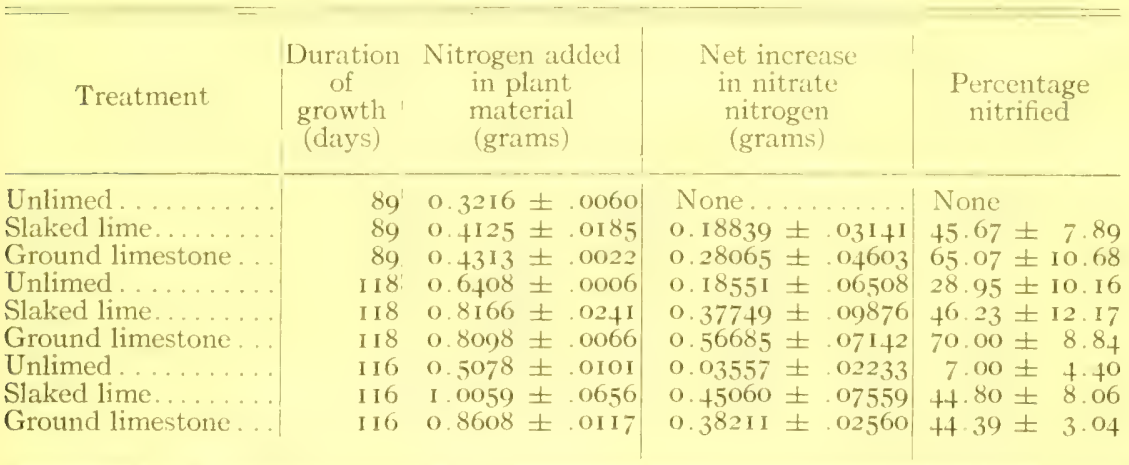

from the tables in which the yields are recorded. It is assumed that these figures, obtained by analysis of the crops removed, should approximate the nitrogen added in the material turned under in the duplicate pots. The values for net increase in nitrate nitrogen were obtained from those showing the net gain in nitrates in parts per million due to the crop turned under. The later values were changed to grams of nitrogen by taking account of the amount of soil present in each pot. It is realized, of course, that all of this nitrogen may not have been formed from the plant material added. However, the figures do represent the net increase in nitrate nitrogen as a result of turning under the crops, 
and thus it seems proper to use them in computing the value for percentage nitrified. The probable error of a given value for the latter was obtained according to the formula given by Mellor, ${ }^{7}$

$$
E= \pm \frac{\sqrt{\left(\frac{B a}{A}\right)^{2}+b^{2}}}{A},
$$

in which $A$ is the divisor with a probable error $a$, and $B$ is the dividend with a probable error $b$.

It appears unwise to make any very definite statements regarding the data in table 12 , both because of the computations involved in constructing the table and because of the large probable error attached to many of the values. It is believed, however, that the table is useful in showing the approximate amount of nitrification resulting from turning under the various crops. The values for percentage nitrified for the unlimed pots vary widely, and nothing can be said about them except that they show that the added material nitrified less rapidly than in the limed pots. There is no consistent difference shown by the two forms of lime, neither is there any evidence to show that the crop grown for the shorter period nitrified more rapidly. For the three periods of growth the figures showing the percentage nitrified for the crop treated with slakerl lime auree very closely; on the other hand, the figures for the pots receiving ground limestone vary rather widely. As a rough figure to indicate the percentage of the added nitrogen nitrified in the limed pots, 50 per cent might be chosen.

\section{SUMMARY}

In an investigation such as the one described in this paper, repetitions of the experiments under field conditions are desirable before general conchusions are drawn. The results obtained in the present study must be interpreted with respect to the experimental conditions maintained. This fact should be borne in mind in considering the summary given.

These experiments show that sweet clover will make a satisfactory growth for use as a green manure in three or four months on a worn-out soil, provided the lime recuirement is satisfied. When the crop is harvested at either of these periods it compares favorably in nitrogen content with other lesumes, and sufficient fiber has not developed to inhibit rapid decay. Growing the crop for the longer period does not result in an increased proportion of fiber. The plant responds readily to inoculation with the appropriate organism. To secure a sourl stand, the seedbed

\footnotetext{
7 Mellor, J. W. Higher mathematics for students of chemistry and physics, p. 529. 1905.
} 
should be comprat and treated seert should be used. The use of treated seed is important also from the standpoint of economy. Treating the seed with acid increases the pereentage of sermination threefold, and seed so treated does not lose its increased serminating power for at least ten months. Satisfying the lime requirement of the soil was found to increase the yield 50 per cent for the crop grown four months.

A crop of sweet clover grown for three or four months decays rapidly when used as yreen manure. It was found that in the limed pots sufficient nitrates had been produced four months after harvest to account for approximately 50 per cent of the nitrogen added in the material turned under. From the standpoint of the amount of available plant food, it is desirable that sweet clover. to be used as a green manure, should be grown for at least four months.

The measurement of nitrate formation in pot experiments is subject to a large probable error. This fact is a real objection to the method as a quantitative measure of rate of decay. 


\section{BIBLIOGRAPHY}

Allen, E. R., and Bonazzi, A. On nitrification. Ohio Agr. Exp. Sta. Technical bul. $7:$ I-42. I9I5.

Brown, P. E., AND Allison, F. E. Influence of humus forming materials of different nitrogen-carbon ratios on bacterial actirities. Inwa Agr. Exp. Sta. Research bul. 36:1-30. I916.

Cameron, F. K., and Breazeale, J. F. The organic matter in soils and subsoils. Amer. Chem. Soc. Journ. 26:29-45. Iy>4.

CARr, M. EARL. A preliminary report on the Volusia soils, their problems and management. U. S. Bur. Soils. Bul. 60: I-22. I909.

Fraps. G. S. Studies in nitrification. Amer. chem. journ. 29:225-24I. 1903.

Hill, Harry $H$. The effect of green manuring on soil nitrates under greenhouse conditions. Virginia Agr. Exp. Sta. Technical bul. 6:1 I9-

I I53. I9I5.

Hopkins, Cyrit. G. Soil fertility and permanent agriculture, p. 1-653. I 9 IO.

Hitchinson, C. M., and Mrlmician, S. Green manuring experiment, 1912-I3. India Agr. Research Inst., Pusa. Bul. 40: I-3I. I9I4.

Jones, C. H. Activity of organic nitrogen as measured by the alkaline permanganate method. Journ. indus. and eng. chem. 4:438-44I. I912.

Joves, C. H., AND ANderson, G. F. A procedure for separating organic ammoniates from the mineral purtion of commercial fertilizers. Journ. indus. and eng. chem. 6:580-58I. I9I4.

Lloyd, W. A. Sweet clover. Ohio Agr. Exp. Sta. Bul. 244:589-684. I9I2.

Love, Harry H., and Leighty, Clyde E. Germination of seed as affected by sulphuric acid treatment. Cornell Univ. Agr. Exp. Sta. Bul. 3 $12: 293-336$. I9I 2 .

Lyon, T. Lyttleton, and Bizzell, James A. Some relations of certain higher plants to the formation of nitrates in soils. Cornell Univ. Agr. Exp. Sta. Memoir I : I-III. I9I3.

Muntz, A. Du rôle des engrais verts comme fumure azotée. Acad. Sci. (Paris). Compt. rend. II0:972-975. I890.

ORTh, - Melilotus as green manure for heavy soils. Cited in Exp. sta. rec. 5:701-702. r894. From Braunschw. Landw. Ztg. 60 ${ }^{38}: 160$. I 892 .

Punoll, - Recherches sur l'azote assimilable et sur ses transformations dans la terre arable. Acad. Sci. (Paris). Compt. rend. I20: 8 I $2-8$ 5. I 895 .

PATERSon, John W., And ScotT, P. R. Influence of certain soil constituents upon nitrification. Victoria Dept. Agr. Journ. 10:393-400. I () I ? 
Veitch, IF. P. The estimation of soil acidity and the lime requirement of soils. Amer. Chem. Soc. Journ. 24: I120-1128. I902.

Westgate, J. M., and Vinall, H. N. Siveet clover. U. S. Dept. Agr. Farmers' bul. 485 : I-39. I9I 2 .

Woncyy, E. Leber die Thatigkeit nedriger Uryanismen in der Ackererde. Centbl. Agr. Chem. 13:796-8I4. I884. (Abstracted from Deut. landw. Presse, vol. Io, I883, and vol. II, I 884.$)$

Untersuchungen über die Zersetzung der organischen Substanzen. Journ. Landw. 34:2 I3-320. I 886.

Wright, R. Claude. The influence of certain organic materials upon the transformation of soil nitrogen. Amer. Soc. Agron. Journ. 7: 193208. I9I5. 




